\title{
The Spindle Tree, Euonymus europaea L. (Celastraceae): A Newly Naturalized Shrub in Nova Scotia
}

\author{
DAVID J. Garbary ${ }^{1}$ and Amy E. Deveau \\ ${ }^{1}$ Department of Biology, St. Francis Xavier University, Antigonish, Nova Scotia B2G 2W5 Canada; e-mail: dgarbary@ gmail.com
}

Garbary, David J., and Amy E. Deveau. 2007. The Spindle Tree, Euonymus europaea L. (Celastraceae): a newly naturalized shrub in Nova Scotia. Canadian Field-Naturalist 121(1): 85-88.

Over 100 plants, including over 750 individual shoots, of Euonymus europaea L. are reported from the Town of Antigonish in northern Nova Scotia. Plants were found in five discrete areas separated by $200-1000 \mathrm{~m}$. A few individuals at one site may represent human planting; however, over $90 \%$ of plants occur on waste ground or in dense shrubbery where natural colonization has occurred. Many individuals were observed in fruit in the fall of 2005, and over 95\% of the plants had well developed buds and flowers in May and early June 2006. Euonymus europaea is considered a newly naturalized species for the flora of Nova Scotia.

Key Words: Spindle Tree, Euonymus europaea, introductions, naturalized, Nova Scotia.

Euonymus (Celastraceae) is a cosmopolitan genus of over 200 species of vines, deciduous and evergreen shrubs, and small trees (Gleason and Cronquist 1991). Many species are ornamentals because of their colourful fruits and fall foliage and their unusual winged stems. At least six species are recorded from Canada, of which one is regarded as doubtful (Scoggan 1978; Catling 1997; Hinds 2000). Only E. occidentalis Nutt. ex Torr. (Western Wahoo), E. atropurpurea Jacq. (Eastern Wahoo) and E. obovata Nutt. (Running StrawberryBush) are native in Canada, with E. occidentalis restricted to the west coast. Euonymus europaea L., E. fortunei (Turcz.) Hand.-Mazz., E. alata (Thun.) Siebold, and $E$. nana Bieb. are escapes from cultivation in eastern Canada, although they have restricted distributions in New Brunswick (Catling 1997; Hinds 2000). Other species occur in the northeastern United States (i.e., E. alata and E. americana L., Gleason and Cronquist 1991). No species is included in the flora of Nova Scotia (Zinck 1998).

Euonymus europaea was first noted in Antigonish as a single, non-cultivated plant in 2001 in Antigonish County, Nova Scotia (DJG unpublished). In a subsequent survey during fall and early winter of 20052006 (Garbary and Taylor 2007), fruiting plants of $E$. europaea were noted from the previously recognized site as well as additional sites in Antigonish. The species likely represents an escape from cultivation. Here we report E. europaea as a newly naturalized plant in Nova Scotia.

\section{Materials and Methods}

During the course of plant surveys in late fall and early winter of 2001 and 2005-06 (Taylor and Garbary 2003; Garbary and Taylor 2007), fruiting specimens of Euonymus europaea were noted. In May 2006, when flower buds were well developed but unopened, a sur- vey of all previously identified locations was undertaken. Further surveys were conducted to determine the size of the overall population in Antigonish and the extent to which the species was reproducing. The four primary sites are designated as University, Claymore, Hospital, and Brierly Brook (see Table 1). Two additional sites with only 1-2 primary plants were found but are not included in Table 1.

Sites were surveyed with hand-held GPS units (Garmin 12, Olathe, Kansas, USA). The largest stem in any cluster was considered the primary plant, and adjacent shoots were assumed to be derived from the same base, or progeny from seed. The height of the largest plant at each site was measured with a meter stick, and the numbers of subsidiary shoots and nearby juveniles were counted. These data were gathered to demonstrate that plants were successfully reproducing in the area. For each primary plant, the slope, exposure to full sunlight, proximity to water (ditches, ponds or saturated soil) and reproductive condition were recorded. The number of flower buds on each peduncle was counted on the population on St. Francis Xavier University. Voucher specimens are deposited in the herbarium of St. Francis Xavier University (STFX) with duplicates deposited in herbariums of ACAD (Acadia University) and NSPM (Nova Scotia Provincial Museum).

\section{Results}

With its opposite leaves on short petioles, the longitudinal whitish markings on many young stems that often gives them a four-angled outline, and the brilliant scarlet and orange fruits, Euonymus europaea is a distinctive species during all seasons (Figure 1).

Most primary shoots (>95\%) and many adjacent smaller plants had abundant clusters of flower buds in mid- to late May 2006. The bud scales of branch buds and developing inflorescences had red tips and a ciliate 
B

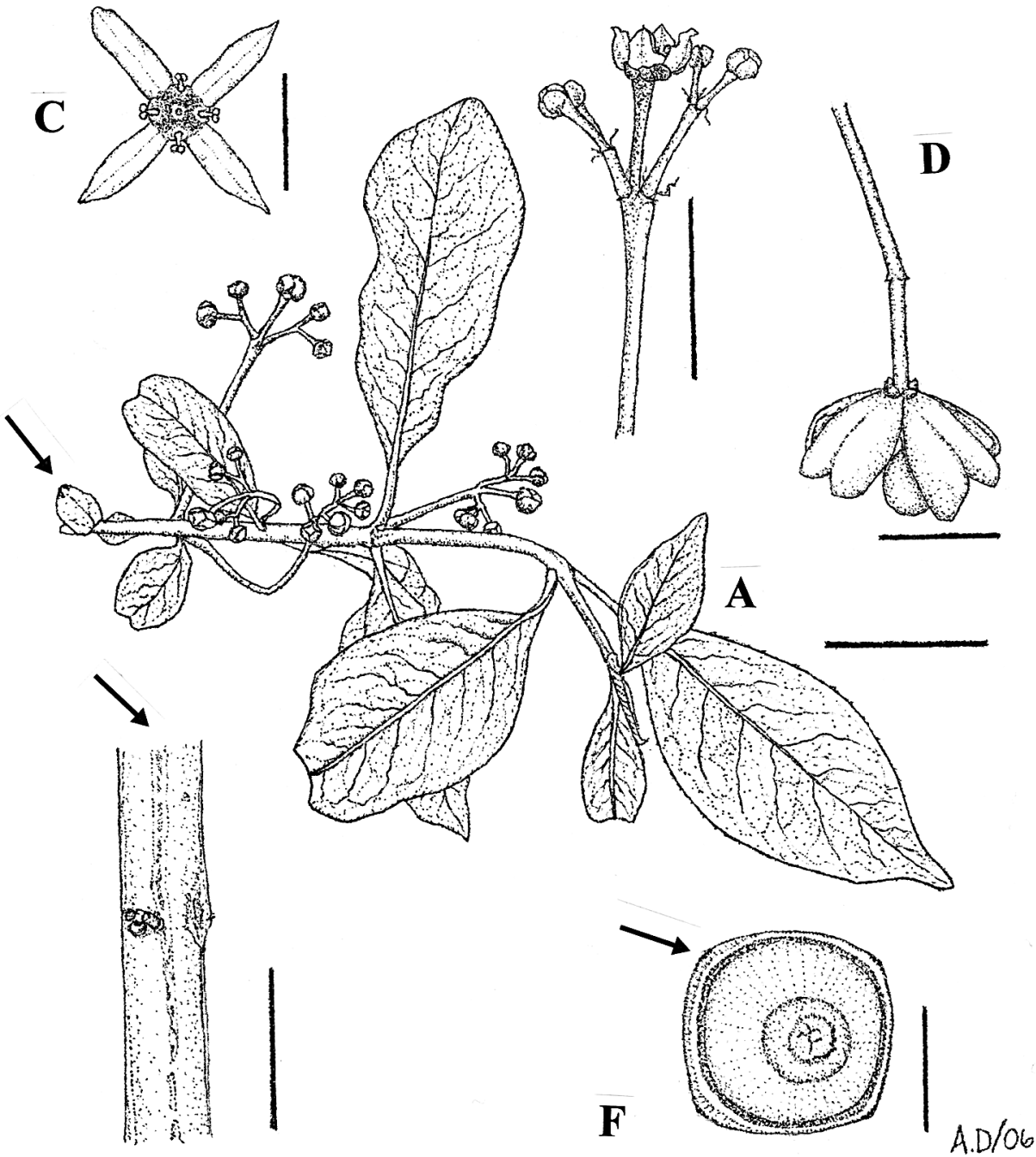

$\mathbf{E}$

FIGURE 1. Euonymus europaea from Antigonish. A) Branch with leaves, developing inflorescences and bud scale (arrow). Scale $=2 \mathrm{~cm}$. B) Inflorescence with central bud partially open. Scale $=1 \mathrm{~cm}$. C) Fully open flower. Scale $=5 \mathrm{~mm}$. D) Mature fruit after dehiscence showing single seed. Scale $=1 \mathrm{~cm}$. E) Longitudinal view of stem showing leaf scar and longitudinal ridge on bark (arrow). Scale $=2 \mathrm{~cm}$. F) Transverse section of stem showing squarish outline and position of longitudinal ridges. Scale $=5 \mathrm{~mm}$.

margin. Flowers did not open until late May when a single bud in each peduncle opened. The flowers are not conspicuous, and plants are cryptic against a background of the larger and showier species of Prunus, Crataegus and Amelanchier. The flowers are ca. $1 \mathrm{~cm}$ diameter, and have diagnostic greenish-white petals. The flowering peduncles had from 1-9 buds $(5.0 \pm 1.8)$, with most inflorescences having odd numbers of buds.
Over 100 primary plants over $50 \mathrm{~cm}$ high and over 650 secondary shoots and adjacent progeny were found at six locations in Antigonish (Table 1). The primary axes were $1.5 \pm 0.8 \mathrm{~m}$ (mean \pm s.d.) tall, and many plants were over $3 \mathrm{~m}$ (Figure 2) with a trunk diameter of up to $6 \mathrm{~cm}$. There was wide variation $(0->50)$ in number of secondary shoots and progeny associated with each primary plant, although about $30 \%$ had 


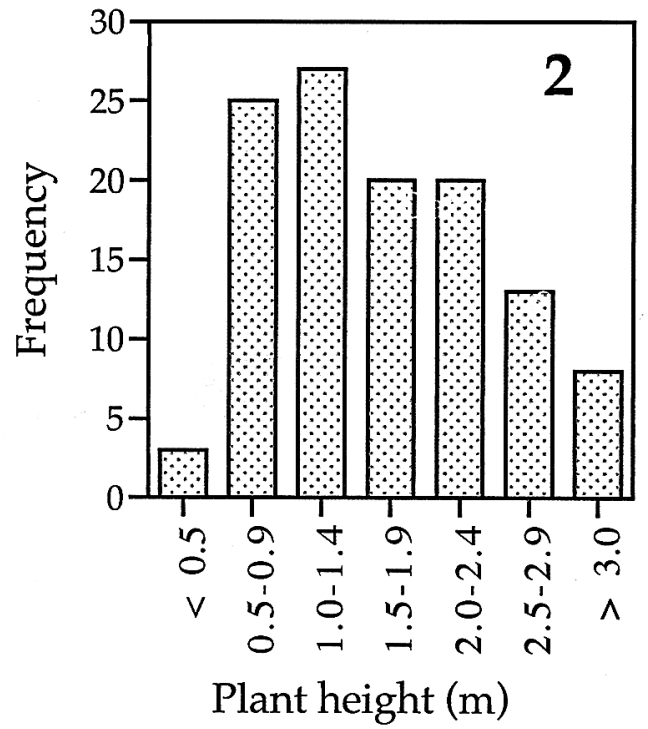

FIGURE 2. Histogram showing sizes of 112 primary stems of Euonymus europaea from Antigonish.

only 1-2 additional axes (Figure 3 ). The largest single clump was at the Brierly Brook site. It occupied about $4 \times 3 \mathrm{~m}$ and had about 50 separate stems that formed a dense thicket.

Plants were typically found in the open where they experienced full sun, or at the edges of dense shrub thickets where they were either crowded or overtopped by the surrounding plants. Most plants grew in moist locations. Plants in the open tended to occur on boggy ground, and plants were common close to ditches, ponds or small pools or on the flood plain of a stream. Some plants were present on steep slopes on ground with obvious seeps. Only a few plants occurred on drier soils; these were in grass on mowed areas and may have been planted.

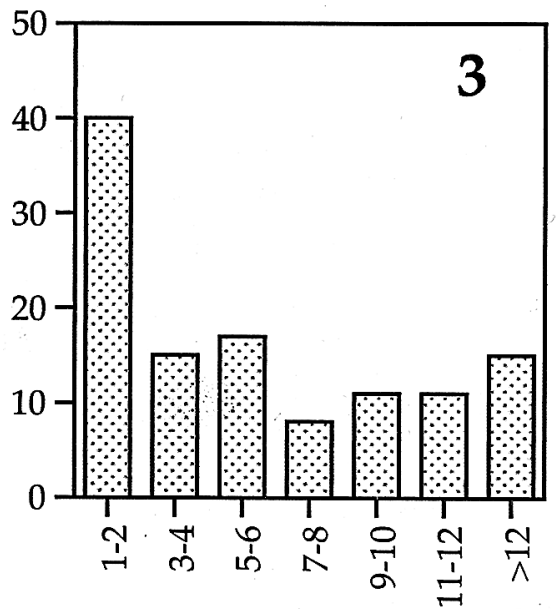

Number of shoots

FIGURE 3. Histogram showing number of secondary shoots and possible progeny associated with each primary plant.

\section{Discussion}

All of the Euonymus plants we observed were $E$. europaea. The plants are scattered over several square kilometres in at least five separate sites. The abundance of small plants within $3 \mathrm{~m}$ of larger individuals and widely scattered small plants (i.e., less than $1 \mathrm{~m}$ ) show that successful seed germination is occurring. These observations are consistent with the definition of naturalized of Pysek et al. (2004); i.e., that successful reproduction has been occurring for at least ten years in the vicinity of the parent plant.

The site where most of the plants were found is an open field where E. europaea is mixed with many other shrubs. These shrubs are mostly widely scattered and

TABLE 1. Populations of Euonymus europaea in Antigonish. Additional sites with only one or two primary plants not included in the table.

\begin{tabular}{lllll}
\hline \hline & Hospital & Claymore & Brierly Brook & University \\
\hline Latitude and longitude & $45^{\circ} 37.743^{\prime} \mathrm{N}$ & $45^{\circ} 37.056^{\prime} \mathrm{N}$ & $45^{\circ} 37.3944^{\prime} \mathrm{N}$ & $45^{\circ} 37.074^{\prime} \mathrm{N}$ \\
& $61^{\circ} 59.033^{\prime} \mathrm{W}$ & $61^{\circ} 58.877^{\prime} \mathrm{W}$ & $61^{\circ} 59.179^{\prime} \mathrm{W}$ & $61^{\circ} 59.182^{\prime} \mathrm{W}$ \\
Number of primary plants & 12 & 4 & 5 & 90 \\
Secondary shoots and juveniles & 61 & 11 & 95 & 683 \\
Number with flower buds & $11 / 12$ & $4 / 4$ & $5 / 5$ & $87 / 90$ \\
Habitats & Steep slope with & Shrub thicket & Border of & Open areas with \\
& extensive bed of lupins; & beside & hayfield at & herbaceous plants \\
& mowed and unmowed & small stream & margin of thicket & and shrubs; on flat \\
& grassy area & & adjoining stream & ground to steep \\
& & & Plopes \\
Shade & Full sun & Partial to heavy & Partial to high & Full sun but some \\
& & shade & shade & heavily shaded \\
\hline \hline
\end{tabular}


have an overall cover of less that $15 \%$. The occasional individuals that we observed in dense shrubbery had few secondary shoots. Thus, once vegetation closes in, E. europaea may not be able to establish or spread. Species with fleshy fruits have low ability to recruit under a canopy of E. europaea relative to nine other tall shrub species (Kollmann and Grubb 1999). This has not yet become important in Antigonish, since we have observed only one continuous canopy of E. europaea.

Some Euonymus species, including E. alata, have become invasive in several northeastern and midwestern states (e.g., http://tncweeds.ucdavis.edu/alert/ alrteuon.html) following escape from ornamental plantings. E. alata is considered a threat in woodland areas, fields and coastal scrubland, where it can outcompete native species. There is no record of $E$. europaea as a problematic invasive species, although it has become widely naturalized in central Canada. Montgomery (1957) refers to sites where it has become "very common" in woods. The abundance of mature and immature individuals in Antigonish suggests that this is possible for E. europaea in Nova Scotia. The extensive field survey carried out by DJG in the fall and early winter of 2005-2006 identified four of the sites reported here. Additional surveys in 20062007 did not reveal further populations. While there are no specimens based on wild collections of $E$. europaea in other local herbaria (i.e., NSPM, ACAD, NSAC [Nova Scotia Agriculture Canada]), other urban areas may be expected to host wild plants (e.g., Wolfville, Nova Scotia - Sam Vander Kloet, personal communication). To satisfy the Pysek et al. (2004) definition of invasive, many offspring must be produced at a distance from the parent individuals. The limited dispersal of E. europaeus in Antigonish has not yet satisfied this criterion.

\section{Acknowledgments}

We thank Greg Power, Kelly Clement and Meghan Hines for assistance with fieldwork, Randy Lauff who pointed out the location of an additional Euonymus site, and Barry Taylor for comments on the manuscript. Curators of ACAD, NSPM and NSAC provided information and access to collections. This research was supported by research grants from the Natural Sciences and Engineering Research Council of Canada to DJG.

\section{Literature Cited}

Catling, P. M. 1997. The problem of invading alien trees and shrubs: some observations in Ontario and a Canadian checklist. Canadian Field-Naturalist 111: 338-342.

Garbary, D. J., and B. R. Taylor. 2007. Plant flowering during January in Antigonish County, Nova Scotia. Canadian Field-Naturalist 121(1): 76-80.

Gleason, H. A., and A. Cronquist. 1991. Manual of vascular plants of Northeastern United States and adjacent Canada, $2^{\text {nd }}$ edition. New York Botanical Garden, Bronx, New York.

Hinds, H. R. 2000. Flora of New Brunswick. University of New Brunswick, Fredericton, New Brunswick. 695 pages.

Kollmann, J., and P. J. Grubb. 1999. Recruitment of fleshyfruited species under different shrub species: control by under-canopy environment. Ecological Research 14: 9-21.

Montgomery, F. H. 1957. The introduced plants of Ontario growing outside of cultivation. Transactions of the Royal Canadian Institute 32: 3-35.

Pysek, P., D. M. Richardson, M. Rejmanek, G. L. Webster, M. Williamson, and J. Kirschner. 2004. Alien plants in checklists and floras: towards better communication between taxonomists and ecologists. Taxon 53: 131-143.

Scoggan, H. J. 1978. The Flora of Canada Part 3 - Dicotyledonae (Sauruaceae to Violaceae). National Museum of Natural Sciences, National Museum of Canada, Ottawa. 568 pages

Taylor, B. R., and D. J. Garbary. 2003. Late-flowering plants from northern Nova Scotia. Rhodora 105: 118-135.

Zinck, M. Editor. 1998. Roland's Flora of Nova Scotia, $3^{\text {rd }}$ edition Nimbus Publishing Ltd. and Nova Scotia Museum, Halifax, Nova Scotia, Canada. 1297 pages.

Received 16 June 2006

Accepted 7 March 2008 